\title{
Algoriphagus aquatilis sp. nov., isolated from a freshwater lake
}

\author{
Ying Liu, ${ }^{1}$ Hao Li, ${ }^{2}$ Jia-Tong Jiang, ${ }^{1}$ Ying-Hao Liu, ${ }^{1}$ Xue-Feng Song, ${ }^{2}$ \\ Cheng-Jun $\mathrm{Xu}^{2}$ and Zhi-Pei Liu ${ }^{1}$
}

Correspondence

Zhi-Pei Liu

liuzhp@sun.im.ac.cn

\author{
${ }^{1}$ State Key Laboratory of Microbial Resources, Institute of Microbiology, Chinese Academy of \\ Sciences, Beijing 100101, PR China \\ ${ }^{2}$ Water Supply Company of Daqing Petroleum Administration, No. 49, Aiguo Road, Ranghulu \\ District, Daqing 163453, PR China
}

\begin{abstract}
A Gram-negative, non-spore-forming, non-motile bacterium, strain $A 8-7^{\top}$, was isolated from fresh water of a slightly alkaline lake, Longhu Lake, in Daqing, north-east China, and its taxonomic position was studied by using a polyphasic approach. Strain A8- $7^{\top}$ was aerobic, heterotrophic and positive for catalase and oxidase. It grew at $20-37{ }^{\circ} \mathrm{C}$ (optimum $30{ }^{\circ} \mathrm{C}$ ) and $\mathrm{pH} 5.5-10.5$ (optimum $\mathrm{pH}$ 7.5) and in the presence of 0-3\% (w/v) $\mathrm{NaCl}$. It formed pink-pigmented, smooth and circular colonies, $1-2 \mathrm{~mm}$ in diameter, on R3A-V agar plates after incubation at $30{ }^{\circ} \mathrm{C}$ for 3 days. Cells of strain A8- $7^{\top}$ were rods, $0.2-0.4 \mu \mathrm{m}$ wide and 1.6-4.0 $\mu \mathrm{m}$ long. The major fatty acids $(>10 \%)$ were iso- $\mathrm{C}_{15: 0}(40.3 \%)$ and summed feature $3\left(\mathrm{C}_{16: 1} \omega 7 \mathrm{c}\right.$ and/or iso- $\mathrm{C}_{15: 0} 2-$ $\mathrm{OH} ; 12.1 \%)$. The menaquinone was MK-7. The DNA G $+\mathrm{C}$ content was $43 \mathrm{~mol} \%\left(T_{\mathrm{m}}\right)$. Phylogenetic analyses based on 16S rRNA gene sequences revealed that strain A8- $7^{\top}$ was phylogenetically related to members of the genus Algoriphagus, with sequence similarities of 92.6-95.2\%, the highest sequence similarity being to the sequence from Algoriphagus mannitolivorans IMSNU $14012^{\top}$. On the basis of phenotypic, chemotaxonomic and phylogenetic data, strain A8- $7^{\top}$ was considered to represent a novel species of the genus Algoriphagus, for which the name Algoriphagus aquatilis sp. nov. is proposed. The type strain is $A 8-7^{\top}$ (=CGMCC $1.7030^{\top}=$ NBRC $104237^{\top}$ ).
\end{abstract}

The genus Algoriphagus was proposed by Bowman et al. (2003) for heterotrophic, Gram-negative, non-motile, strictly aerobic, pink-pigmented and rod-shaped bacteria, and was initially described as accommodating cold-adapted micro-organisms because strains of the type species, Algoriphagus ratkowskyi, were isolated from sea ice and from saline lake cyanobacterial mats collected in Antarctica (Bowman et al., 2003). Later, mesophilic Algoriphagus species were isolated and the description of the genus was emended (Nedashkovskaya et al., 2004, 2007). Members of the genus Algoriphagus form a phylogenetic cluster with the genera Hongiella (Yi \& Chun, 2004) and Chimaereicella (Tiago et al., 2006). Based on phylogenetic evidence and chemotaxonomic and phenotypic data, the genera Hongiella and Chimaereicella were combined with the genus Algoriphagus by Nedashkovskaya et al. (2007). At the time of writing, the genus Algoriphagus comprises 16

The GenBank/EMBL/DDBJ accession number for the 16S rRNA gene sequence of $A 8-7^{\top}$ is EU313811.

Maximum-parsimony and maximum-likelihood trees based on 16S rRNA gene sequences and a table of cellular fatty acid contents of strain A8$7^{\top}$ and strains of other Algoriphagus species are available as supplementary material with the online version of this paper. species with validly published names: Algoriphagus ratkowskyi (the type species; Bowman et al., 2003), Algoriphagus aquimarinus, Algoriphagus chordae and Algoriphagus winogradskyi (Nedashkovskaya et al., 2004), Algoriphagus halophilus (Yi \& Chun, 2004; Nedashkovskaya et al., 2004), Algoriphagus antarcticus (Van Trappen et al., 2004), Algoriphagus yeomjeoni (Yoon et al., 2005a), Algoriphagus locisalis (Yoon et al., 2005b), Algoriphagus (Hongiella) mannitolivorans and Algoriphagus (Hongiella) ornithinivorans (Yi \& Chun, 2004), Algoriphagus (Hongiella) marincola (Yoon et al., 2004), Algoriphagus (Chimaereicella) alkaliphilus (Tiago et al., 2006), Algoriphagus (Chimaereicella) boritolerans (Ahmed et al., 2007), Algoriphagus terrigena (Yoon et al., 2006), Algoriphagus vanfongensis (Nedashkovskaya et al., 2007) and Algoriphagus hitonicola (Copa-Patiño et al., 2008). In this study, we report the isolation and taxonomic characterization of an Algoriphagus-like bacterium, strain A8- $7^{\mathrm{T}}$, which was isolated from surface water of a slightly alkaline lake, Longhu Lake, in Daqing, north-east China $\left(46^{\circ} 43^{\prime} \mathrm{N} 124^{\circ} 24^{\prime} \mathrm{E}\right)$.

Longhu Lake has the following characteristics: depth, $3.0 \mathrm{~m}$; pH 8.9; $23{ }^{\circ} \mathrm{C}$; chemical oxygen demand, $25 \mathrm{mg}$ 
$\mathrm{l}^{-1}$; biological oxygen demand, $15 \mathrm{mg}^{-1}$; total nitrogen, $1.1 \mathrm{mg} \mathrm{l}^{-1}$; total phosphorus, $0.10 \mathrm{mg} \mathrm{l}^{-1}$. For isolation, a serial dilution of a surface-water sample was spread on loworganic Luria-Bertani agar plates $\left(1^{-1}: 1.0 \mathrm{~g}\right.$ tryptone (Difco), $0.5 \mathrm{~g}$ yeast extract (Difco) and $10.0 \mathrm{~g} \mathrm{NaCl}$; $\mathrm{pH}$ 8.0) and incubated at $30{ }^{\circ} \mathrm{C}$ for 2 days. Subcultures of strain A8- $7^{\mathrm{T}}$ were performed using R3A-V medium (Tiago et al., 2006) or YP medium (containing $\mathrm{l}^{-1}: 3.0 \mathrm{~g}$ tryptone, 3.0 g yeast extract, $\left.0.5 \mathrm{~g} \mathrm{MgSO}{ }_{4} \cdot 7 \mathrm{H}_{2} \mathrm{O}, 0.3 \mathrm{~g} \mathrm{NaCl}\right)$. Strain A $8-7^{\mathrm{T}}$ cannot grow in marine 2216 medium (Difco).

Routine cultivation was conducted at $30{ }^{\circ} \mathrm{C}$ with $\mathrm{R} 3 \mathrm{~A}-\mathrm{V}$ agar. Motility and morphology were observed using phasecontrast microscopy and scanning electron microscopy (Quanta 200; FEI). Flagellation was examined with tannin staining according to Dong \& Cai (2001) and transmission electron microscopy (H600; Hitachi). The Gram reaction was determined by Gerhardt et al. (1994).

Catalase and oxidase activities and hydrolysis of casein, gelatin, aesculin, L-tyrosine, starch and Tweens 20, 40, 60 and 80 were determined as described by Cowan \& Steel (1965). $\mathrm{H}_{2} \mathrm{~S}$ production was determined by Bruns et al. (2001). Growth under anaerobic conditions was determined by incubation in an anaerobic chamber with anaerobically prepared YP broth. Growth at various $\mathrm{NaCl}$ concentrations $(0-3.5 \%$, in increments of $0.5 \%$, w/v) was investigated in $\mathrm{R} 3 \mathrm{~A}-\mathrm{V}$ broth. Growth at various temperatures was tested using $\mathrm{R} 3 \mathrm{~A}-\mathrm{V}$ broth and agar at $\mathrm{pH} 8$ by incubation at various temperatures $(16,20,25,30,35,37$ and $40{ }^{\circ} \mathrm{C}$ ). The $\mathrm{pH}$ range for growth was determined in YP broth adjusted to $\mathrm{pH} 5.0-11.0$, in increments of $0.5 \mathrm{pH}$ units, using $1 \mathrm{M} \mathrm{NaOH}$ or $1 \mathrm{M} \mathrm{HCl}$.

The presence of flexirubin-like pigments was tested according to Fautz \& Reichenbach (1980). Extracellular glycans were identified with the Congo red absorption test (McCammon \& Bowman, 2000). In vivo pigment absorption spectrum analysis was examined as described by Yoon et al. (2004) using a Unico UV-2802H spectrophotometer (Shanghai Optical Company).
Carbon source assimilation was determined using API 50 $\mathrm{CH}$ test strips (bioMérieux), using $0.1 \mathrm{M}$ Tris/ $\mathrm{HCl}$ buffer, pH 8.0, supplemented with API AUX medium (bioMérieux). Acid production from various substrates was determined using API $50 \mathrm{CH}$ test strips and $50 \mathrm{CHB} / \mathrm{E}$ medium (bioMérieux) according to the manufacturer's instructions. Additional biochemical properties and enzyme activities were detected with the API 20NE and API ZYM systems (bioMérieux) according to the manufacturer's instructions. Susceptibility to antibiotics was determined on R3A-V agar plates using filter-paper discs (Beijing Pharmaceutical Company) containing various antibiotics, specified in the species description. All above tests were performed in triplicate.

Genomic DNA extraction, PCR and sequencing of the $16 \mathrm{~S}$ rRNA gene were carried out according to the procedures given by Kim et al. (1998). The almost-complete nucleotide sequence of the 16S rRNA gene (1484 nt) was compared with available 16S rRNA gene sequences in the GenBank database using the BLAST program (Altschul et al., 1990) at NCBI (http://www.ncbi.nlm.nih.gov). Multiple alignment with sequences of close relatives was performed by using the Clustal x program (Thompson et al., 1994) and phylogenetic analyses were then carried out using neighbour-joining (Saitou \& Nei, 1987), maximum-parsimony (Fitch, 1971) and maximum-likelihood (Felsenstein, 1981) treeing algorithms. A phylogenetic tree was reconstructed with the neighbour-joining method from the calculated evolutionary distances. Phylogenetic analyses based on the $16 \mathrm{~S}$ rRNA gene revealed that strain $\mathrm{A} 8-\mathrm{7}^{\mathrm{T}}$ was phylogenetically related to members of the genus Algoriphagus, with sequence similarities of 92.6-95.2\%, the highest similarity being shown to the sequence from $A$. mannitolivorans IMSNU $14012^{\mathrm{T}}$. Strain A8-7 ${ }^{\mathrm{T}}$, together with A. mannitolivorans IMSNU $14012^{\mathrm{T}}$, formed a distinct phylogenetic lineage within the genus Algoriphagus (Fig. 1), indicating that it was likely to represent a novel species of the genus Algoriphagus. This phylogenetic placement was also found in trees constructed using the maximum-parsimony and

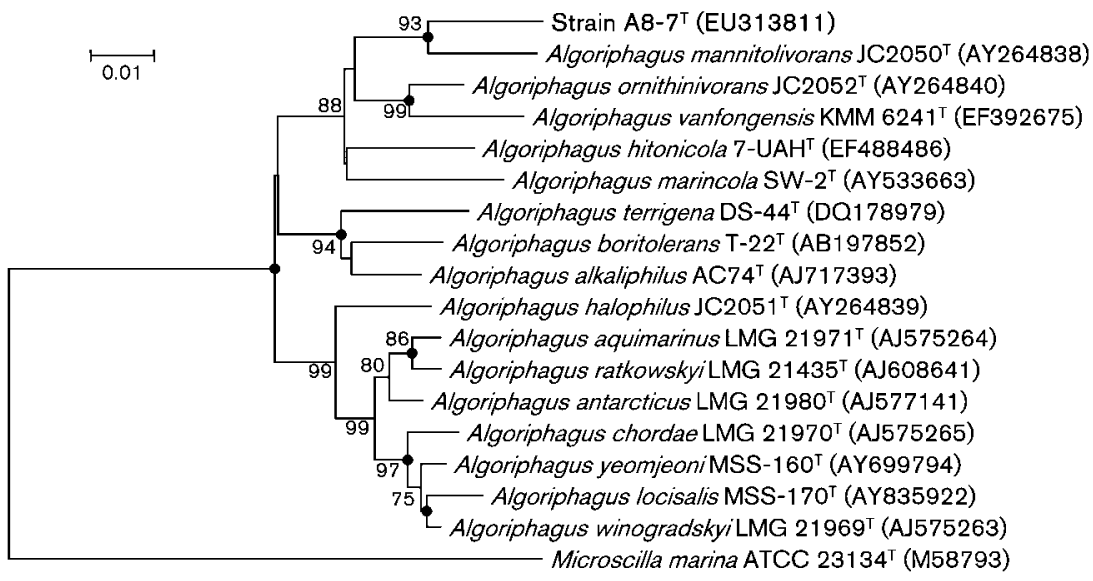

Fig. 1. Neighbour-joining tree based on $16 \mathrm{~S}$ rRNA gene sequences showing the phylogenetic position of strain $A 8-7^{\top}$ and representatives of some other related taxa. Bootstrap values (expressed as percentages of 1000 replications) $>70 \%$ are shown at branch points. Filled circles indicate branches that were also recovered using both maximumlikelihood (Felsenstein, 1981) and maximumparsimony (Fitch, 1971) tree-making algorithms. The sequence of Microscilla marina ATCC $23134^{\top}$ was used as an outgroup. Bar, 0.01 substitutions per nucleotide position. 
Table 1. Differential properties of strain $A 8-7^{\top}$ and the type strains of other Algoriphagus species

Strains: 1, Algoriphagus aquatilis sp. nov. A8- $7^{\mathrm{T}} ; 2$, A. mannitolivorans JC2050 ${ }^{\mathrm{T}}$ (data from Yi \& Chun, 2004); 3, A. alkaliphilus AC74 ${ }^{\mathrm{T}}$ (Tiago et al., 2006); 4, A. boritolerans T-22 ${ }^{\mathrm{T}}$ (Ahmed et al., 2007); 5, A. ornithinivorans JC2052 ${ }^{\mathrm{T}}$ (Yi \& Chun, 2004); 6, A. halophilus JC2051 ${ }^{\mathrm{T}}$ (Yi \& Chun, 2004); 7, A. terrigena DS- $44^{\mathrm{T}}$ (Yoon et al., 2006); 8, A. marincola SW- $2^{\mathrm{T}}$ (Yoon et al., 2004); 9, A. hitonicola 7-UAH ${ }^{\mathrm{T}}$ (Copa-Patiño et al., 2008); 10, A. vanfongensis KMM $6241^{\mathrm{T}}$ (Nedashkovskaya et al., 2007); 11, A. aquimarinus KMM 3958 ${ }^{\mathrm{T}}$ (Nedashkovskaya et al., 2004); 12, A. winogradskyi KMM $3956^{\mathrm{T}}$ (Nedashkovskaya et al., 2004); 13, A. ratkowskyi IC025 ${ }^{\mathrm{T}}$ (Bowman et al., 2003); 14, A. antarcticus LMG 21980 ${ }^{\mathrm{T}}$ (Van Trappen et al., 2004); 15, A. locisalis MSS- $170^{\mathrm{T}}$ (Yoon et al., 2005b); 16, A. yeomjeoni MSS-160 ${ }^{\mathrm{T}}$ (Yoon et al., 2005a); 17, A. chordae KMM 3957 ${ }^{\mathrm{T}}$ (Nedashkovskaya et al., 2004). All strains are positive for catalase, alkaline phosphatase and aesculin hydrolysis. +, Positive; -, negative; w, weakly positive; $\mathrm{V}$, variable; ND, no data available.

\begin{tabular}{|c|c|c|c|c|c|c|c|c|c|c|c|c|c|c|c|c|c|}
\hline Nitrate reduction & - & + & + & - & - & - & + & $\mathrm{V}$ & + & - & - & + & $\mathrm{V}$ & - & - & - & - \\
\hline $\mathrm{NaCl}$ for growth (\%) & $0-3$ & $0-7$ & $0-3$ & $0-3$ & $0-10$ & $0-8$ & $1-7$ & $1-9$ & $1.5-5$ & $0-8$ & $0-10$ & $0-6$ & $0-6$ & $0-5$ & $1-9$ & $1-9$ & $1-10$ \\
\hline Casein & $\mathrm{w}$ & - & - & $\mathrm{ND}$ & - & - & + & + & ND & - & + & - & + & - & - & + & - \\
\hline Gelatin & - & + & + & - & + & + & - & - & $\mathrm{ND}$ & + & + & + & $\mathrm{V}$ & - & - & $\mathrm{V}$ & - \\
\hline Starch & + & + & + & + & + & + & - & + & + & - & - & + & $\mathrm{V}$ & - & - & - & - \\
\hline Tween 20 & + & - & ND & $\mathrm{ND}$ & - & + & + & + & $\mathrm{ND}$ & - & + & + & + & $\mathrm{ND}$ & + & + & + \\
\hline Tween 40 & + & - & ND & $\mathrm{ND}$ & + & + & + & + & ND & - & + & + & + & $\mathrm{ND}$ & + & + & + \\
\hline Tween 80 & + & - & ND & $\mathrm{ND}$ & + & + & + & + & - & - & + & - & - & $\mathrm{ND}$ & + & + & - \\
\hline $\mathrm{H}_{2} \mathrm{~S}$ production & + & - & - & - & - & - & - & - & - & - & - & - & - & - & - & - & - \\
\hline Oxidase, $\beta$-galactosidase & + & + & + & + & + & + & + & + & - & + & + & + & + & + & + & + & + \\
\hline \multicolumn{18}{|l|}{ Acid production from: } \\
\hline Lactose & $\mathrm{w}$ & - & + & + & - & - & + & + & + & - & + & + & - & - & + & + & + \\
\hline Maltose & $\mathrm{w}$ & - & + & + & - & + & + & + & + & + & - & + & + & - & + & + & + \\
\hline D-Mannose & $\mathrm{w}$ & - & + & + & - & $\mathrm{ND}$ & + & + & + & + & + & + & + & - & + & - & + \\
\hline Melibiose & $\mathrm{w}$ & - & + & - & - & - & + & + & + & - & + & + & + & - & + & + & + \\
\hline L-Rhamnose & - & - & - & + & - & - & - & - & - & + & + & + & + & - & + & + & + \\
\hline Sucrose & $\mathrm{w}$ & + & + & - & - & + & + & + & + & - & + & + & - & - & + & + & + \\
\hline D- and L-Xylose & - & - & - & - & - & + & + & + & - & + & + & + & + & - & + & + & + \\
\hline$N$-Acetyl-D-glucosamine & - & - & - & + & - & + & $\mathrm{ND}$ & - & + & + & + & + & + & - & $\mathrm{ND}$ & - & - \\
\hline \multicolumn{18}{|l|}{ Utilization of: } \\
\hline L-Arabinose & - & + & + & - & - & + & + & + & $\mathrm{ND}$ & + & + & + & + & - & + & - & + \\
\hline D-Glucose, maltose, D-mannose & + & + & + & + & + & + & + & + & $\mathrm{ND}$ & + & + & + & + & - & + & + & + \\
\hline D-Mannitol & - & + & - & + & - & - & - & - & - & - & + & - & + & - & - & - & - \\
\hline
\end{tabular}

maximum-likelihood methods (Supplementary Fig. S1, available in IJSEM Online).

The $\mathrm{G}+\mathrm{C}$ content of the DNA was determined by thermal denaturation (Marmur \& Doty, 1962) and DNA from Escherichia coli $\mathrm{K}-12$ was used as a control. The DNA G $+\mathrm{C}$ content of strain $\mathrm{A} 8-7^{\mathrm{T}}$ was $43 \mathrm{~mol} \%\left(T_{\mathrm{m}}\right)$, which is within the range reported for the genus Algoriphagus (3544 mol\%; Nedashkovskaya et al., 2007).

Cells of strain $\mathrm{A} 8-7^{\mathrm{T}}$ were non-motile, non-spore-forming rods, $0.2-0.4 \mu \mathrm{m}$ wide and 1.6-4.0 $\mu \mathrm{m}$ long. Colonies on R3A-V or YP medium were pink, smooth, circular, convex and 1-2 $\mathrm{mm}$ in diameter after incubation for 3 days. Colony colour was variable and dependent on the $\mathrm{pH}$.
Faint pink pigmentation was found after growth on alkaline medium $(>\mathrm{pH} 8)$. The absorption maximum of crude extracts was $485 \mathrm{~nm}$, which is similar to other members of the genus Algoriphagus (Copa-Patiño et al., 2008; Yi \& Chun, 2004; Yoon et al., 2004).

Cellular fatty acid content was determined by the MIDI Sherlock Microbial Identification System (Microbial ID) with cells grown on $\mathrm{R} 3 \mathrm{~A}-\mathrm{V}$ plates at $30{ }^{\circ} \mathrm{C}$ for 3 days, according to the manufacturer's instructions. Strain $\mathrm{A} 8-7^{\mathrm{T}}$ had a fatty acid profile similar to those of closely related Algoriphagus species (Supplementary Table S1). The dominant fatty acids were iso- $\mathrm{C}_{15: 0}(40.3 \%)$ and summed feature $3\left(\mathrm{C}_{16: 1} \omega 7 c\right.$ and/or iso- $\left.\mathrm{C}_{15: 0} 2-\mathrm{OH} ; 12.1 \%\right)$, which are also the dominant fatty acids for other members of the 
genus Algoriphagus. Isoprenoid quinones were extracted and analysed as described by Komagata \& Suzuki (1987). Strain A8- $7^{\mathrm{T}}$ contained MK-7 as the sole respiratory menaquinone, as for other members of the genus Algoriphagus.

Some phenotypic properties of strain A8- $7^{\mathrm{T}}$, such as its being strictly aerobic and heterotrophic, the production of non-diffusible pigments and the presence of oxidase and catalase activities, in addition to its chemotaxonomic characteristics, suggested that it should be placed in the genus Algoriphagus. However, several properties, including hydrolysis of gelatin, starch, DNA and Tweens 20, 40 and $80, \mathrm{H}_{2} \mathrm{~S}$ production, acid production from several carbohydrates and the utilization of several carbon sources, differentiated strain $\mathrm{A} 8-\mathrm{7}^{\mathrm{T}}$ from other species of the genus Algoriphagus (Table 1).

On the basis of the evidence described above, strain A8- $7^{\mathrm{T}}$ is considered to represent a novel species of the genus Algoriphagus, and the name Algoriphagus aquatilis sp. nov. is proposed.

\section{Description of Algoriphagus aquatilis sp. nov.}

Algoriphagus aquatilis (a.qua'ti.lis. L. masc. adj. aquatilis aquatic, pertaining to the isolation of the type strain from fresh water).

Exhibits the following properties in addition to those given in Table 1. Cells are Gram-negative, non-motile, nonspore-forming rods, $0.2-0.4 \mu \mathrm{m}$ wide and $1.6-4.0 \mu \mathrm{m}$ long. Positive for catalase. Strictly aerobic and heterotrophic. Growth occurs at $20-37{ }^{\circ} \mathrm{C}$ (optimum $30{ }^{\circ} \mathrm{C}$ ) and $\mathrm{pH} 5.5-$ 10.5 (optimum pH 7.5) and in the presence of $0-3 \%(\mathrm{w} / \mathrm{v})$ $\mathrm{NaCl}$ (optimum 0.5-1\%). Flexirubin-type pigments and glycans are absent. Negative for urease and arginine dihydrolase. Indole is not produced. Hydrolyses L-tyrosine and Tween 60. With API ZYM tests, strong activity is observed for leucine arylamidase, valine arylamidase, trypsin, $\alpha$-chymotrypsin, acid phosphatase, naphthol-ASBI-phosphohydrolase, $\alpha$-galactosidase, $\alpha$-glucosidase, $\beta$ glucosidase and $N$-acetyl- $\beta$-glucosaminidase, weak activity for esterase (C4), esterase lipase (C8), cystine arylamidase, $\beta$-galactosidase and $\beta$-mannosidase, but no activity for lipase (C14), $\beta$-glucuronidase and $\alpha$-fucosidase. Produces acid weakly from D-galactose, methyl $\alpha$-D-glucoside, aesculin, salicin, cellobiose, trehalose, raffinose, starch, gentiobiose and turanose, but not from glycerol, erythritol, D-ribose, D-adonitol, methyl $\beta$-D-xylopyranoside, L-sorbose, dulcitol, inositol, D-mannitol, D-sorbitol, methyl $\alpha$-Dmannoside, amygdalin, arbutin, melezitose, glycogen, xylitol, D-tagatose, D- or L-fucose, D- or L-arabitol, potassium gluconate, potassium 2-ketogluconate or potassium 5-ketogluconate. Utilizes methyl $\alpha$-D-glucoside, amygdalin, cellobiose, lactose, melibiose, sucrose, trehalose, melezitose, raffinose, starch, glycogen, gentiobiose and turanose, weakly utilizes erythritol, D-adonitol, D-fructose, dulcitol, arbutin and salicin, but does not utilize glycerol, $\mathrm{D}-$ or $\mathrm{L}$-arabinose, $\mathrm{D}$-ribose, $\mathrm{D}-$ or $\mathrm{L}$-xylose, methyl $\beta$-Dxylopyranoside, D-galactose, L-sorbose, L-rhamnose, inosi- tol, methyl $\alpha$-D-mannoside, inulin, xylitol, D-tagatose, D- or L-fucose, D- or L-arabitol, potassium gluconate, potassium 2-ketogluconate or potassium 5-ketogluconate. The major fatty acids are iso- $\mathrm{C}_{15: 0}$ and summed feature $3\left(\mathrm{C}_{16: 1} \omega 7 c\right.$ and/or iso- $\left.\mathrm{C}_{15: 0} 2-\mathrm{OH}\right)$. The major menaquinone is MK-7. Antibiotic sensitivity results as follows ( $\mu$ g per disc unless otherwise stated): resistant to vancomycin (30); weakly resistant to ampicillin (10) and penicillin (10 IU); susceptible to gentamicin (10), carbenicillin (100), polymixin B (300 IU), streptomycin (10), tetracycline (30), kanamycin (30), erythromycin (15), novobiocin (5), chloramphenicol (30), ciprofloxacin (5), norfloxacin (10) and rifampicin (5). The DNA G+C content of the type strain is $43 \mathrm{~mol} \%\left(T_{\mathrm{m}}\right)$.

The type strain is A8- $7^{\mathrm{T}}\left(=\mathrm{CGMCC} 1.7030^{\mathrm{T}}=\mathrm{NBRC}\right.$ $104237^{\mathrm{T}}$ ), isolated from fresh water of the slightly alkaline Longhu Lake, Daqing city, north-east China.

\section{Acknowledgements}

This work was supported by grants from the high-tech development program of China (863 program no. 2006AA06Z316).

\section{References}

Ahmed, I., Yokota, A. \& Fujiwara, T. (2007). Chimaereicella boritolerans sp. nov., a boron-tolerant and alkaliphilic bacterium of the family Flavobacteriaceae isolated from soil. Int J Syst Evol Microbiol 57, 986-992.

Altschul, S. F., Gish, W., Miller, W., Myers, E. W. \& Lipman, D. J. (1990). Basic local alignment search tool. J Mol Biol 215, 403-410.

Bowman, J. P., Nichols, C. M. \& Gibson, J. A. E. (2003). Algoriphagus ratkowskyi gen. nov., sp. nov., Brumimicrobium glaciale gen. nov., sp. nov., Cryomorpha ignava gen. nov., sp. nov. and Crocinitomix catalasitica gen. nov., sp. nov., novel flavobacteria isolated from various polar habitats. Int J Syst Evol Microbiol 53, 1343-1355.

Bruns, A., Rohde, M. \& Berthe-Corti, L. (2001). Muricauda ruestringensis gen. nov., sp. nov., a facultatively anaerobic, appendaged bacterium from German North Sea intertidal sediment. Int $J$ Syst Evol Microbiol 51, 1997-2006.

Copa-Patiño, J. L., Arenas, M., Soliveri, J., Sánchez-Porro, C. \& Ventosa, A. (2008). Algoriphagus hitonicola sp. nov., isolated from an athalassohaline lagoon. Int J Syst Evol Microbiol 58, 424-428.

Cowan, S. T. \& Steel, K. J. (1965). Manual for the Identification of Medical Bacteria. London: Cambridge University Press.

Dong, X.-Z. \& Cai, M.-Y. (2001). Determinative Manual for Routine Bacteriology. Beijing: Scientific Press (English translation).

Fautz, E. \& Reichenbach, H. (1980). A simple test for flexirubin-type pigments. FEMS Microbiol Lett 8, 87-91.

Felsenstein, J. (1981). Evolutionary trees from DNA sequences: a maximum likelihood approach. J Mol Evol 17, 368-376.

Fitch, W. M. (1971). Toward defining the course of evolution: minimum change for a specific tree topology. Syst Zool 20, 406-416.

Gerhardt, P., Murray, R. G. E., Wood, W. A. \& Krieg, N. R. (1994). Methods for General and Molecular Bacteriology. Washington, DC: American Society for Microbiology.

Kim, S. B., Falconer, C., Williams, E. \& Goodfellow, M. (1998). Streptomyces thermocarboxydovorans sp. nov. and Streptomyces 
thermocarboxydus sp. nov., two moderately thermophilic carboxydotrophic species from soil. Int J Syst Bacteriol 48, 59-68.

Komagata, K. \& Suzuki, K. (1987). Lipid and cell-wall analysis in bacterial systematics. Methods Microbiol 19, 161-207.

Marmur, J. \& Doty, P. (1962). Determination of the base composition of deoxyribonucleic acid from thermal denaturation temperature. $J$ Mol Biol 5, 109-118.

McCammon, S. A. \& Bowman, J. P. (2000). Taxonomy of Antarctic Flavobacterium species: description of Flavobacterium gillisiae sp. nov., Flavobacterium tegetincola sp. nov. and Flavobacterium xanthum sp. nov., nom. rev. and reclassification of [Flavobacterium] salegens as Salgentibacter salegens gen. nov., comb. nov. Int J Syst Evol Microbiol 50, 1055-1063.

Nedashkovskaya, O. I., Vancanneyt, M., Van Trappen, S., Vandemeulebroecke, K., Lysenko, A. M., Rohde, M., Falsen, E., Frolova, G. M., Mikhailov, V. V. \& Swings, J. (2004). Description of Algoriphagus aquimarinus sp. nov., Algoriphagus chordae sp. nov. and Algoriphagus winogradskyi sp. nov., from sea water and algae, transfer of Hongiella halophila Yi and Chun 2004 to the genus Algoriphagus as Algoriphagus halophilus comb. nov. and emended descriptions of the genera Algoriphagus Bowman et al. 2003 and Hongiella Yi and Chun 2004. Int J Syst Evol Microbiol 54, 1757-1764.

Nedashkovskaya, O. I., Kim, S. B., Kwon, K. K., Shin, D. S., Luo, X., Kim, S.-J. \& Mikhailov, V. V. (2007). Proposal of Algoriphagus vanfongensis sp. nov., transfer of members of the genera Hongiella Yi and Chun 2004 emend. Nedashkovskaya et al. 2004 and Chimaereicella Tiago et al. 2006 to the genus Algoriphagus, and emended description of the genus Algoriphagus Bowman et al. 2003 emend. Nedashkovskaya et al. 2004. Int J Syst Evol Microbiol 57, 1988 1994.
Saitou, N. \& Nei, M. (1987). The neighbor-joining method: a new method for reconstructing phylogenetic trees. Mol Biol Evol 4, 406425.

Thompson, J. D., Higgins, D. G. \& Gibson, T. J. (1994). CLUSTAL W: improving the sensitivity of progressive multiple sequence alignment through sequence weighting, position-specific gap penalties and weight matrix choice. Nucleic Acids Res 22, 4673-4680.

Tiago, I., Mendes, V., Pires, C., Morais, P. V. \& Verissimo, A. (2006). Chimaereicella alkaliphila gen. nov., sp. nov., a Gram-negative alkaliphilic bacterium isolated from a nonsaline alkaline groundwater. Syst Appl Microbiol 29, 100-108.

Van Trappen, S., Vandecandelaere, I., Mergaert, J. \& Swings, J. (2004). Algoriphagus antarcticus sp. nov., a novel psychrophile from microbial mats in Antarctic lakes. Int J Syst Evol Microbiol 54, 1969-1973.

Yi, H. \& Chun, J. (2004). Hongiella mannitolivorans gen. nov., sp. nov., Hongiella halophila sp. nov. and Hongiella ornithinivorans sp. nov., isolated from tidal flat sediment. Int J Syst Evol Microbiol 54, 157-162.

Yoon, J.-H., Yeo, S.-H. \& Oh, T.-K. (2004). Hongiella marincola sp. nov., isolated from sea water of the East Sea in Korea. Int J Syst Evol Microbiol 54, 1845-1848.

Yoon, J.-H., Kang, S.-J., Jung, S.-Y., Lee, C.-H. \& Oh, T.-K. (2005a). Algoriphagus yeomjeoni sp. nov., isolated from a marine solar saltern in the Yellow Sea, Korea. Int J Syst Evol Microbiol 55, 865-870.

Yoon, J.-H., Kang, S.-J. \& Oh, T.-K. (2005b). Algoriphagus locisalis sp. nov., isolated from a marine solar saltern. Int J Syst Evol Microbiol 55, 1635-1639.

Yoon, J.-H., Lee, M.-H., Kang, S.-J. \& Oh, T.-K. (2006). Algoriphagus terrigena sp. nov., isolated from soil. Int J Syst Evol Microbiol 56, 777780. 